\title{
T cell immunodeficiency in dyskeratosis congenita
}

\author{
B W Lee, H K Yap, T C Quah, A Chong, C C Seah
}

\begin{abstract}
Dyskeratosis congenita has been found to be associated with abnormal immune function. In this study we report a patient with this association. He developed Pneumocystis carinii interstitial pneumonia, and impaired cell mediated immunity was confirmed by the presence of depressed lymphoproliferative responses to in vitro stimulation with mitogen. Enumeration of $\mathbf{T}$ cell subsets showed a severely depressed CD4:CD8 ratio (0.38), which is the likely cause for impaired cell mediated immunity. The $T$ cell activation pathway appeared intact, as his $\mathrm{T}$ lymphocytes were able to express activation markers (CD25 and HLA-DR) after mitogen stimulation.
\end{abstract}

Dyskeratosis congenita is a rare, heritable, multisystem disorder, characterised by reticulate skin hyperpigmentation, mucosal leucoplakia, and nail dystrophy. More serious features are bone marrow involvement with pancytopenia and a predisposition to malignancy. Although the primary defect has not been identified, an X linked mode of inheritance has been shown in the majority of cases. ${ }^{1}$ Recently, linkage in one large family by using $\mathrm{X}$ chromosome specific RFLP markers has assigned the gene for dyskeratosis congenita to chromosome band $\mathrm{Xq} 28 .{ }^{2}$ Several families with apparent autosomal forms of dyskeratosis congenita have also been reported, suggesting aetiological heterogeneity in this disorder. ${ }^{34}$

Chromosome breakage is not a consistent finding, although enhanced $G_{2}$ chromatid radiosensitivity has been observed in the fibroblasts. ${ }^{5}$ This phenomenon has been observed in individuals genetically predisposed to cancer, ${ }^{6}$ a characteristic also observed in dyskeratosis congenita. Patients with this disorder are also prone to opportunistic infections, and immunological abnormalities which include both humoral and cell mediated dysfunction. We report a case of dyskeratosis congenita with abnormalities in $\mathrm{T}$ cell subsets and impaired lymphoproliferative responses to in vitro stimulation with mitogens.

Paediatrics,

National University

of Singapore

B W Lee

H K Yap

T C Quah

A Chong

C C Seah

Correspondence to:

Dr Lee Bee Wah,

Division of Nephrology,

Immunology, and Urology,

Department of Paediatrics,

National University

of Singapore,

Lower Kent Ridge Road,

Singapore 0511 .

Accepted 18 December 1991 Case study

A 15 year old boy presented with characteristic dermatological features of dyskeratosis congenita which he had had since the age of 3 years. These included reticulate skin pigmentation, dystrophic nails, and oral mucosa leucoplakia. He had been immunised, including BCG, without complications. At the age of 10 years he had developed thrombocytopenia, which had pro- gressed over the next few years to pancytopenia associated with bone marrow hypoplasia. At this stage a bone marrow transplantation was considered, but his parents refused consent. At the age of 15 he developed Pneumocystis carinii interstitial pneumonia, which was confirmed by the presence of protozoan cysts in the bronchial alveolar lavage. He responded to treatment with intravenous high dose co-trimoxazole. His male cousin (maternal side) was also similarly affected with dyskeratosis congenita, and died from sepsis at the age of 10 years.

His total white counts fluctuated from 6.4 to $0 \cdot 8 \times 10^{9} / 1$, with absolute lymphocyte counts of 2.5 to $<0.8 \times 10^{9} / 1$. Serum immunoglobulin concentrations showed raised $\operatorname{IgG} 21 \cdot 2 \mathrm{~g} / \mathrm{l}$, with normal concentrations of IgA $2 \cdot 09 \mathrm{~g} / \mathrm{l}$, and IgM $2 \cdot 1 \mathrm{~g} / \mathrm{l}$. HIV antibody was absent. Delayed hypersensitivity skin test to the purified protein derivative (10 unit dose) was negative, suggesting anergy.

\section{Materials and methods}

ISOLATION OF BLOOD MONONUCLEAR CELLS

Blood mononuclear cells (BMC) were prepared from heparinised blood by the standard FicollHypaque gradient.

\section{CELL MARKERS}

Cell surface expression of $\mathrm{T}$ cell subsets was assessed by indirect immunofluorescence using monoclonal antibodies against CD3, CD4, CD8 (Becton Dickinson). Half a million BMC were suspended in $100 \mu \mathrm{l}$ Roswell Park Memorial Institute medium 1640 (RPMI-1640) supplemented with $2.5 \%$ fetal bovine serum and $0.01 \%$ sodium azide (staining buffer) and incubated with the respective monoclonal antibodies for 30 minutes on ice. This was followed by washing in staining buffer and a similar incubation with fluorescein isothiocyanate conjugated affinity purified goat antimouse immunoglobulin. The cells were then washed extensively and analysed using the FACScan flow cytometer (Becton Dickinson).

To assess the ability of $T$ lymphocytes to express activation antigens upon stimulation with mitogen, cells were stimulated with phytohaemagglutinin $0.5 \mu \mathrm{g} / \mathrm{ml}$. After a 48 hour incubation, the stimulated cells were stained separately with fluorescein-conjugated monoclonal antibodies against CD25 or HLA-DR, and phycoerythrin-conjugated CD3. The cells were read by two colour fluorescence analysis using the FACScan flow cytometer. 
Table 1 Expression of the T activation markers CD25 and HLA-DR, shown by percentage increase in these factors

\begin{tabular}{|c|c|c|c|c|}
\hline & \multicolumn{2}{|l|}{ Control } & \multicolumn{2}{|l|}{ Patient } \\
\hline & $C D 3 C D 25$ & CD3 HLA-DR & $\overline{C D 3 C D 25}$ & $C D 3 H L A-D R$ \\
\hline $\begin{array}{l}\text { Medium } \\
\text { PHA } 12.5 \mu \mathrm{g} / \mathrm{ml}\end{array}$ & $\begin{array}{l}11 \\
98\end{array}$ & $\begin{array}{r}8 \\
25\end{array}$ & $\begin{array}{l}15 \\
92\end{array}$ & $\begin{array}{l}17 \\
25\end{array}$ \\
\hline
\end{tabular}

PHA, phytohaemagglutinin.

Table 2 Lymphoproliferative responses to mitogens

\begin{tabular}{llllll}
\hline & \multicolumn{3}{l}{${ }^{3}$ H-thymidine incorporation (counts/min) } \\
\cline { 2 - 3 } & Expt 1 & & Expt 2 \\
\cline { 2 - 3 } \cline { 5 - 6 } & Control & Patient & Control & Patient \\
\hline Medium & 750 & 228 & 804 & 350 \\
Phytohaemagglutinin & 86070 & 39725 & & 105721 & 30250 \\
Concanavalin A & 30279 & 8305 & 85615 & 10125 \\
\hline
\end{tabular}

LYMPHOPROLIFERATIVE RESPONSES

Lymphocẏte proliferative responses to the mitogens, phytohaemagglutinin $(0.5 \mu \mathrm{g} / \mathrm{ml})$ and concanavalin A $(10 \mu \mathrm{g} / \mathrm{ml})$ were assessed in microtitre plates containing $1 \times 10^{5} \mathrm{BMC}$ suspended in RPMI-1640 supplemented with $10 \%$ fetal bovine serum, $2 \mathrm{mM}$ L-glutamine and 100 $\mathrm{U} / \mathrm{ml}$ penicillin and $50 \mu \mathrm{g}$ streptomycin. Cells were pulsed with $1 \mu \mathrm{Ci}$ per well of tritiated thymidine (Amersham International) after 72 hours, and harvested 16-24 hours later using an automated cell harvester. Cell uptake of tritiated thymidine were then counted using a $\beta$ scintillation counter (Beckman). Lymphocyte stimulation was assessed by the difference between the triplicate stimulated cultures and the unstimulated cultures measured in mean counts per minute.

\section{Results}

Evaluation of $T$ cell numbers and subsets showed normal percentage of $\mathrm{CD} 3$ positive cells $(76 \%)$. There was a reversal of CD4:CD8 ratio (which now measured 0.38 ), with percentages of CD4 and CD8 of $21 \%$ and $55 \%$, respectively. The absolute numbers of CD4 positive cells were depressed $\left(0 \cdot 19 \times 10^{9} / 1\right.$; normal range $\left.0.25-1.33 \times 10^{9} / 1\right)$, although the absolute numbers of CD8 positive cells were normal $\left(0.50 \times 10^{9} / 1\right.$; normal range $\left.0 \cdot 18-1 \cdot 18 \times 10^{9} / 1\right)$. Similar values were obtained on two other occasions. Although the lymphocytes were able to express the activation markers CD25 and HLA-DR after in vitro stimulation with phytohaemagglutinin (table 1), the lymphoproliferative response to phytohaemagglutinin and concanavalin A was impaired (table 2).

These results indicate the presence of impaired cell mediated immune responses in this patient with dyskeratosis congenita. This depression is likely to be contributed by the reversal of the CD4:CD8 ratio and the decrease in absolute numbers of $\mathrm{CD} 4$ positive cells. The ability of the patient's $T$ cells to express activation markers upon mitogen stimulation suggests an intact $T$ cell activation pathway.

\section{Discussion}

Dyskeratosis congenita is a genetic condition which is ultimately lethal. We have previously reported the characteristic mucocutaneous features in two of our local patients with this disease. ${ }^{7}$ Abnormalities in immune function in this disorder is evidenced by a high incidence of unusual infections, and the primary causes of death are infections and carcinoma. In this study, our patient with dyskeratosis congenita and depressed cell mediated immunity developed interstitial pneumonia due to $P$ carinii infection; this is an opportunistic infection usually affecting patients with depressed $\mathrm{T}$ cell function.

There have been other reports of abnormalities of cell mediated immunity in dyskeratosis congenita. These have included absence or delayed hypersensitivity to a battery of skin test antigens, ${ }^{3}$ and impaired response to mitogenic stimulation upon in vitro testing. ${ }^{8}$ Our patient also showed impaired lymphoproliferative responses to in vitro stimulation with mitogens (table 2). The mechanism for the impaired cell mediated function has not been delineated. As shown in this study, the presence of a markedly depressed CD4:CD8 ratio $(0.38)$ and decrease in absolute CD4 positive cells are likely contributing factors. The $\mathrm{T}$ cell activation pathway appears to be intact since the patient's $T$ cells were able to express normally the activation marker CD25 and HLA-DR (table 1). Expression of these receptors upon lymphocyte activation are an important feature of cellular immunity, as abnormalities in their expression have resulted in severe combined immunodeficiency syndrome. 910

There have also been reports that suggest abnormalities of humoral immunity in patients with dyskeratosis congenita. A wide range of immunoglobulin abnormalities have been reported, including diffuse hypoglobulinaemia, ${ }^{11}$ decreased IgG and IgM with normal IgA, ${ }^{8}$ normal IgG and IgA with slightly decreased IgM, ${ }^{12}$ and increased IgG. ${ }^{13}$ Our patient had hypergammaglobulinaemia. With the presence of cell mediated abnormality, as seen in our patient, it is tempting to postulate that the dysgammaglobulinaemia may result from abnormal $T$ cell help, similar to that seen in paediatric acquired immune deficiency syndrome. ${ }^{14}$ Interestingly, the genes for dyskeratosis congenita and $\mathrm{X}$ linked severe combined immunodeficiency, a condition also associated with depressed cellular and humoral immunity, have both been located on the long arm of the $X$ chromosome. Their locations on the long arm of the $\mathrm{X}$ chromosome differ, with the former located in the $\mathrm{Xq} 28^{2}$ band and the latter between region $\mathrm{Xq13.1}$ and $\mathrm{Xq} 21.1 .^{15}$

This study was supported by National University of Singapore Research grants RP 880369 and RP 880337.

1 Sirinavin C, Trowbridge AA. Dyskeratosis congenita: clinica features and genetic aspects. F Med Genet 1975;12:339-54.

2 Connor JM, Gatherer D, Gray FC, Pirrit LA, Affara NA. Assignment of the gene for dyskeratosis congenita to Xq28. Hum Genet 1986;72:348-51.

3 Scoggins RB, Prescott KJ, Asher GH, Blaylock WK, Bright RW. Dyskeratosis congenita with Fanconi-type anemia: 1971;19:409-10.

4 Tchou P-K, Kohn T. Dyskeratosis congenita: An autosoma dominant disorder. F Am Acad Dermatol 1982;6:1034-9. 
5 Debauche DM, Pai GŠ, Stanley WS. Enhanced G2 chromatid radiosensitivity in dyskeratosis congenita. Am $\mathcal{F}$ Hum Genet radiosensitivity

6 Parshad RJ, Sanford KK, Jones GM, Tarone RE. Chromosomal radiosensitivity during the $G_{2}$ cell-cycle period of somal radiosensitivity during the $G_{2}$ cell-cycle period of
skin fibroblasts from individuals with familial cancer. Proc skin fibroblasts from individuals with
Natl Acad Sci USA 1985;82:5460-3.

7 Lee BW, Yap HK, Wong HB, Giam YK. Two cases of dyskeratosis congenita presenting with aplastic anaemia. F Singapore Paediatr Soc 1982;24:156-8.

8 Ortega JA, Swanson VL, Landig BH, Hammond GD. Congenital dyskeratosis: Zinner-Engman-Cole syndrome with thymic dysplasia and aplastic anemia. Am $\mathcal{F}$ Dis Child 1972;124:701-4.

9 Rosen FS, Wedgewood RJ, Eibb M, et al. Primary immunodeficiency diseases. Report of a World Health Organi scientific group. Clin Immunol Immunopathol 1986;40: $166-96$

10 Doi S, Saiki O, Tanaka T, et al. Cellular and genetic analysis of IL-2 production and IL-2 receptor expression in a patient with familial T-cell dominant immunodeficiency. patient with familial T-cell dominant imm

11 Borrone C, Dagna Bricarelli F, Astrice C. Congenital dyskeratosis and immunological defect. Boll Ist Sieroter Milan 1974:53(suppl):265.

12 Gutman A, Frumkin A, Adam A, Bloch-Schtacher N, Rozenszajn LA. X-linked dyskeratosis congenita with pancytopenia. Arch Dermatol 1978;114:1667-71.

13 Steier W, VanVoolen GA, Selmanowitz VJ. Dyskeratosis congenita: relationship to Fanconi anemia. Blood 1972;39: $510-21$

14 Bernstein LJ, Ochs HD, Wedgwood RJ, et al. Defective humoral immunity in pediatric acquired immune deficiency syndrome. F Pediatr 1985;107:352-7.

15 Puck JM, Nussbaum R, Smead DL, Conley ME. X-linked combined immunodeficiency localization within the region Xq13.1-q21 1 by linkage and deletion analysis. $A m \mathcal{F} H u m$ Genet 1989;44:724-30. 